Article

\title{
Integrating Land Change Science and Savanna Fire Models in West Africa
}

\section{Paul Laris}

Department of Geography, California State University, 1250 Bellflower Blvd. Long Beach, CA 90840, USA; E-Mail: plaris@ csulb.edu; Tel.: +1-562-985-2357; Fax: +1-562-985-8993

Received: 12 September 2013; in revised form: 8 November 2013 / Accepted: 11 November 2013 / Published: 18 November 2013

\begin{abstract}
Fire is a key component of many land use systems and a determinant of land change. There is a growing concern that climate change will cause more catastrophic fires, but in many areas the impacts will be mediated by human land use practices. In African savannas, for example, fires are frequent and research finds low inter-annual variability in burned areas in places with highly variable rainfall. This regularity of fire suggests that African regimes are humanized, meaning that they are governed by human practices more than climate variation. Although these fire regimes are stable, they vary greatly over space. This paper will determine the reasons for two distinctly different fire regimes in Mali by integrating land change and savanna fire science. The study takes a two pronged approach to examine the causes of fire regimes and the reasons they change. It tests the notion that land cover (not land use) governs fire regimes by combining long term burn scar and vegetation analysis with local interviews. Results indicate that efforts to link fire and land change science, need to focus more on subtle differences in land cover, landscape pattern and human practices, than on drought, land use or fire policy.
\end{abstract}

Keywords: fire; land use; land cover; savanna; fire triangle

\section{Introduction}

"Yet the historical and ecological relationships between humans, fire and the environment remain ill-defined if not poorly understood and an integrative approach linking the social and physical aspects of fire remains largely unexplored" (Coughlin and Petty 2012 [1], pp. 477). 
"Bin be ni a jeni waati." (Every grass has its appropriate time to burn) (Malian Villager, 2011).

There is a growing concern that climate change will cause larger and more catastrophic fires around the world [2]. Indeed, several high intensity or so-called "mega-fire" events have already been linked to a changing climate [3-5]. Wildfires produce carbon emissions equivalent to $26 \%-31 \%$ of those stemming from fossil fuel combustion and industrial activities [6,7]. What is more, it is thought that increased fire activity will be one of the major drivers of vegetation change under a warming climate resulting in positive feedback loops and possibly even more fire [8-10]. Given the existing impacts of fire on the biosphere and atmosphere, and the potential for major changes in fire regimes as a result of anthropogenic climate change, understanding the mechanisms responsible for rates and directions of fire regime changes are critical research goals. Outside of the recent work linking land use and cover change in rainforest ecosystems, however, little research has examined how changes in land use and cover influence fire regimes. This is especially (and surprisingly) true for the world's savannas which burn more frequently and extensively than any biome on Earth.

The African savannas, which are the Earth's most extensively and frequently burned regions [11], account for some $64 \%$ of the global extent of area burnt annually [12]. Indeed, African savanna fires regularly burn such large areas that they are easily visible from space, so much so that NASA scientists refer to Africa as the "burn center of the planet" [13]. Savanna fires emit large amounts of greenhouse gasses (GHG) and can dramatically alter vegetation cover [14]. The fires are a major source of GHGs including carbon dioxide, methane, and nitrous oxide [15] as well as aerosol particles [12]. Savanna ecosystems support a mixture of grasses and trees, the precise ratio of which varies widely. Moreover, these ecosystems are in disequilibrium and can shift between different states depending on the disturbance regime. In mesic savannas (where precipitation is over $650 \mathrm{~mm}$ per year) fire regimes determine the percentage of tree cover, as well as tree growth rates further affecting the Earth's carbon cycle [16]. Simply put, African savanna fires are a key factor in global climate change.

Critically, in savanna ecosystems it is not the extent of fires, but the fire regime, that strongly effects tree establishment and growth. A fire regime is defined as the frequency, seasonality, intensity, severity, type and spread patterns of fires that prevail in a particular location [17]. As such, determining the factors that regulate different fire regimes in savannas is crucial to understanding the global carbon cycle because of the effects a shift in a fire regime can have on emissions and tree cover. Depending on future fire regimes, savannas could become a source of emissions or a carbon sink. It is important to note that major fire events do not always take the form of a single wildfire, but are sometimes a cluster of inter-acting multiple fires across a large area. Such major fire events often represent a distinct shift in the fire regime of a given area in terms of total area affected [5].

While numerous questions surrounding the science remain, research suggests that fire regimes change as a function of multiple variables rather than climate alone. For example, based on their findings from case studies around the world, Williams and colleagues [5] attribute the rise in mega-fires to three biophysical factors: climate change, fuel accumulation, and increasing landscape homogeneity although the authors also note the important role of policy and fire management. Pyne [3], a fire historian (who notes that the fire community likes to think in terms of triangles to 
explain fire (see below)) also suggests three key factors are responsible for changing fire regimes: climate change, land use, and humanity's fire practices, most notably fire suppression.

In the most general sense a given fire regime is the outcome of the complex interactions between weather, vegetation, and people. The first two have been the focus of much research and while it is clear that climate change will impact these two factors, e.g., [18], it is much less certain as to how and whether human actions will mediate the effects of climate and vegetation changes on fire regimes. Indeed, as the Williams [5] report found, several drought prone areas have low risk of mega-fires. Bird and colleagues [19] have shown, for example, that some Aboriginal burning regimes in Australia serve to decouple fire from drought. Their study documents how the size of naturally caused fires increases dramatically in drought years, while that of human lit fires do not.

In perhaps the most striking deviation from the global pattern, the fire regimes of the African savannas appear to be largely decoupled from the effects of climate. This is especially true for the mesic savannas of western and southern Africa. Although most global models assume strong links between fire and climate, Archibald and colleagues [20] argue that the assumptions underlying these models need to be re-thought in systems such as the African savanna where the, "...human impact on fire regimes...is substantial, and acts to limit the responsiveness of fires to climatic events" ([20], p. 805). Indeed, recent research using global fire databases generated from remotely sensed imagery clearly find that the areas with the lowest interannual variability in fire globally-the savannas of western and southern Africa-are also the most frequently and extensively burned areas [11,21]. Moreover, these same areas are well known for their high interannual variation in precipitation [22]. In short, although African savannas burn a lot, they rarely experience dramatic fire events.

How is it that some of the most fire prone regions on Earth have the most stable fire regimes even in the context of periodic and often severe drought? The answer is that human practices mediate the effects of drought and other factors in these areas producing strongly humanized fire regimes. The term humanized [23] is used here to connote a fire regime that is largely driven by human practices rather than by weather or fuel load, which tend to dictate most fire regimes globally [18]. In an area with a humanized fire regime it is often the number, timing and location of fires, rather than the size of individual ones, that affects how much of the landscape burns [24,25]. As such, researchers seeking to understand fire regimes in savannas need to shift their focus from drought to a variety of other causes that are more likely to result in fire regime changes. What is needed is a rethinking of the common fire models which tend to de-emphasize human factors. Shifts in burning practices and land use, which in turn affect land cover, for example, are more likely to result in a change in fire intensity, severity, seasonality and pattern in areas with humanized regimes and these changes can produce critical biophysical as well as socio-economic consequences.

The goal of this study is to examine the potential for a variety of human and biophysical factors to cause fire regime changes in an area with a humanized fire regime, the Sudanian savanna of Mali. Specifically, this study seeks to integrate land change science and fire models to address three fundamental questions: (i) What human and biophysical factors govern humanized fire regimes?; (ii) Which of these factors have caused detectable changes in fire regimes in recent times?; and (iii) what kinds of changes in savanna fire regimes might be expected in the future given current trends? 
This study will address these questions for an area of frequently and extensively burned savanna in southwestern Mali. The research takes a two pronged approach. First it uses a comparative framework to understand why fire regimes vary between places within a given biogeographic zone. Second, it seeks to understand the causes of changes in fire regimes in an area over time. To develop this approach, it is first necessary to expand upon the traditional fire triangle model.

\section{Conceptual Framework}

\subsection{The Fire Triangle Model}

Fire managers and scientists commonly refer to the fire triangle as a conceptual model for understanding the necessary ingredients for a fire to occur and propagate. In its simplest form, the fire triangle is composed of three elements: oxygen, heat and fuel. If these elements are found in the proper proportions, a fire can occur. Once a fire is started and topography becomes important and the model can be modified to include weather, topography and fuel (see Figure 1).

Figure 1. The Wildfire Triangle.

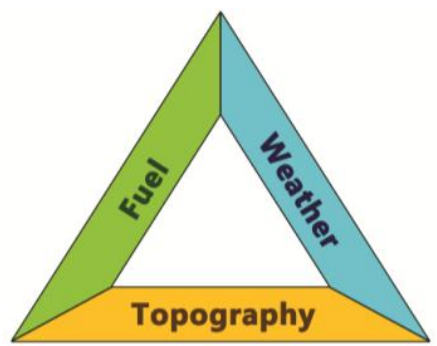

Moritz and colleagues [26] have further developed the triangle to explore long-term fire regimes in the context of a changing climate. As seen in Figure 2 their model begins with the three common variables - ignition, fuel and weather and then each factor is expanded upon. "Oxygen" becomes a function of atmospheric conditions, which in turn are related to climate change. Similarly "fuel" becomes vegetation, which is a function of growth rates and thus also a function of climate. As such, long term averages and interannual variability become the means to study the amount of fire activity. Not surprisingly, little is said about the source of fire ignitions which are simply the sum of lightning strikes and "human caused patterns." As is the case with the wildland fire model, the interplay of weather, topography and fuel determines the behavior of a fire, not human practices.

The main weakness of the models described above; however, is that they fail to consider how each factor is influenced by human actions. Indeed, ignitions are often the only place where human behavior is considered. In areas with humanized fire regimes, however, all three factors in the triangle are influenced by people.

Fuel conditions are affected by people in at least two ways: first, by directly impacting the fuel itself; and second, by indirectly impacting the conditions of the fuel at the time of burning. In the first case, agricultural fallowing cycles, grazing and land clearing practices all impact the spatial pattern of fuel on the landscape as well as the types and densities of fuels that accumulate. For example, farming clearly affects fuel contiguity and type. In mesic savannas, for example, unfarmed areas are often dominated by tall perennial grasses, while fallow lands tend to have shorter annuals. The drying rates and burning 
intensity of these two differ greatly and have important impacts on fire regimes (see below). Fuel load in agricultural landscapes is thus a function of human land use and its history. In the second case, the condition of the fuel is affected by practice - specifically the timing and location of the fire ignition. For example, the intensity and rate of spread of a savanna fire will depend greatly on the fuel-moisture content which declines as the dry season progresses. As such, earlier fires tend to be less intense and due to the natural heterogeneity of landscapes, they spread differently than later fires (e.g., [19,23,27]).

Figure 2. The Fire Regime Triangle (Source: Moritz et al. 2012 [26]).

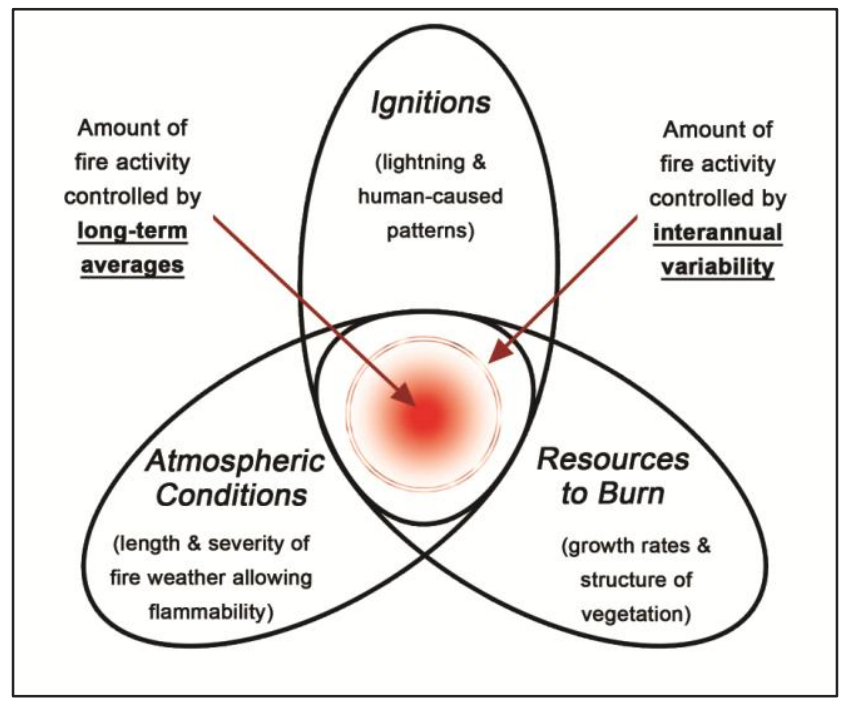

Weather or atmospheric condition may appear a "natural" factor, but this is far from true in many cases. It is important to note that people most often determine when to set fires [28]. They select the time of year, which controls moisture content, and the time of day for ignition, which largely determines the weather conditions including humidity and wind that are changing throughout the day. Many savanna fires are lit in the afternoon, for example, so that they will die down at night. People also determine where to set a fire, and as such they have some control or influence over how a fire will spread with the wind and over the topography. This is as true for prescribed burns in the US as it is for traditional burning in African, South American, or Australian savannas [29].

Ignition is perhaps the most complex factor which may be why it is often ignored or overly simplified. Fire ignition may be the outcome of natural forces, such as lightning or rock-fall or the result of human actions, either intentional or otherwise. Accidental fires have been poorly theorized, but can be thought of in at least three ways: (i) fires that result from non-environmentally related activities (a cigarette thrown from the car window of a passerby, for example), (ii) activities related to environmental uses (such as fires ignited by gunshots associated with hunting) or, (iii) controlled fires that go awry. Purposeful fires are also complicated to define because decisions about setting fires are shaped by human practices and knowledge but they are structured by broader factors such as policy, land tenure, as well as climate changes such as drought.

As the creators of the above models have stressed, fire triangles are based on the interactions of all three factors; and it is therefore important to consider how the three sides of the triangle interact as a function of human practices as well. As such, the relationships can become very complex (see Figure 3). Fuel conditions may be modified by land use changes or fire policy. These changes may in 
turn cause people to alter their burning practices. Similarly, changes in weather, such as a drought, may result in a shift in the timing of fires or efforts to prevent them. Fuel conditions themselves, of course, are also a function of weather and climate. Lastly, it is important to note that in the case of purposeful fires, the above factors are often considered carefully by the individuals or groups setting fires and thus people need to be placed in the very center of any fire model.

Figure 3. The humanized fire triangle.

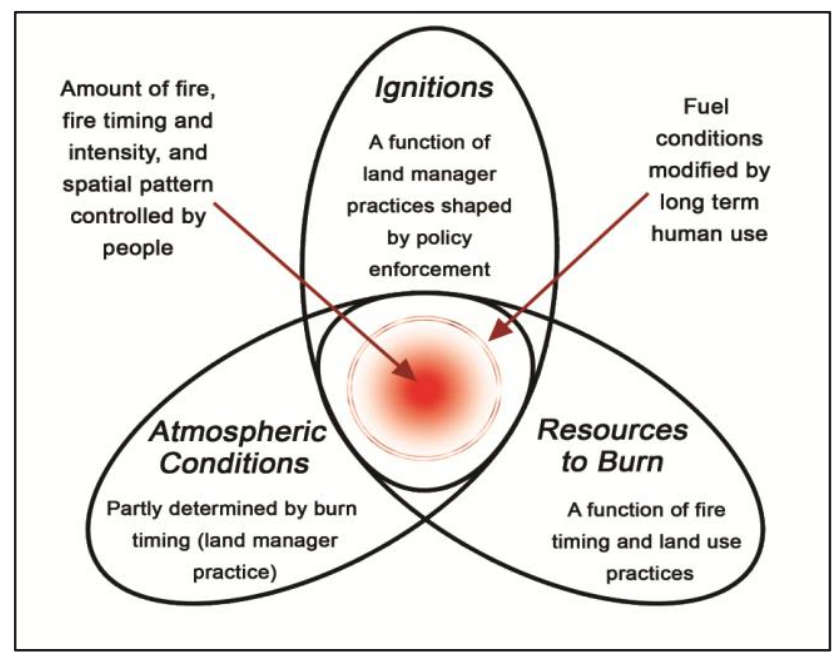

\subsection{Humanizing Fire Regime Models}

A key premise of this research is that in areas where people set most or all fires, fire regimes must be understood by focusing on the actions of individuals that start fires and by placing these individuals within a broader context. Although they were originally writing about land degradation, Blaikie and Brookfield's [30] political ecology approach is a fitting starting point for conceptualizing fire as a land management practice. These scholars developed their approach so as to consider the shifting dialectic between society and land-based resources. Their framework was flexible and took a structure/agency approach whereby individual land managers made land use decisions within the constraints of various structures such as society, a broader economy, and policy. By conceptualizing the fire starter within this broader social (as well as environmental) context, we hope to determine the factors that have the greatest influence on burning and the fire regimes produced.

Numerous studies have documented the logic underlying burning practices of indigenous groups around the world [29]. Less has been written, however, about how these practices are shaped by fire politics and policy. Several key works are illustrative of the role these factors play in determining people's decisions about setting fires. For example, Pyne's [31] landmark treatment of fire history in the US clearly demonstrates that many of the contemporary fire issues of the American West can be linked to key historical events and the political debates they generated. These events ultimately shaped fire policy, which resulted in fire suppression and ultimately contributed to the region's fire problems of today.

Christian Kull [32] has eloquently demonstrated how fire's unique biophysical properties allow for a great deal of human-ecological agency. Fire is a political issue in Madagascar, but as Kull's work showed, even people with little power are quite adept at using fire to accomplish land management 
tasks during times of anti-fire policies. In a similar vein, Laris [33] documented how even the most oppressive of fire suppression policies often do not take hold because people devise clever ways of manipulating fire's unique biophysical properties as they did in Mali in the 1980s. Together these two works show that in highly flammable environments, fire is ubiquitous and enforcement of anti-fire codes rarely succeed in part due to a lack of fire prevention resources but more often due to the agency of people combined with the nature of fire itself. Indeed, it is relatively easy for rural people to resist fire suppression efforts by setting covert fires and by shifting the blame to non-locals such as transients or hunters [29]. Furthermore, people living in flammable environs understand that setting appropriately timed and placed fires (and not fire suppression) is the best way to limit fire damage [28,32,34].

Coughlan and Pettit [1] have recently proposed a framework for humanizing fire regime models. Their approach parallels that of Blaikie and Brookfield [30] by focusing on human agency and practice within the context of a broader spatial and temporal socio-ecological system:

"Agency, knowledge of fire ecology and social systems of production and distribution provide analytical links between human populations and the ecological landscape. Consequently, ignitions ultimately result from human behaviors, and where fire use is practiced, ignitions result from decision process concerning a combination of ecological knowledge and belief and the rationale of livelihood strategies as constrained by social and ecological parameters. The legacy of human land use further influences fuel continuity and hence fire spread" ([1], p. 477).

Importantly, Coughlan and Pettit [1] develop the linkages between three key foci of human-environmental study and fire: human agency, knowledge and practice, and socio-ecological dynamics or history. Recognizing human agency, they point out, compels us to address the question of human decision-making in the acts of setting, pre-empting and suppressing fire. In a nod to the fire triangle model, they point out that while ignitions result from human behavior, fire spread is determined by fuel load and continuity, which are in turn controlled by human land-use practice and land-use legacies.

Although the work of Coughlan and Pettit [1] provides a starting point for a conceptual approach to humanizing fire regimes, there remains a need to develop clearer linkages to the biophysical context. Moreover, their work is largely conceptual and there is thus a need for more empirical studies. In one of the few recent empirical studies specifically focusing on fire regime change, Williams and colleagues [5] conducted a series of case studies on the causes of mega-fires and attributed change to a list of a handful of key factors (see Table 1).

Table 1. Factors affecting fire regime changes resulting in mega-fires [5].

\begin{tabular}{c}
\hline Factors \\
\hline Ignition source \\
Drought and fire weather \\
Fuel conditions and available fuel (especially dead and downed fuel) \\
Vegetation conditions (such as altered forest, shrubland or grassland conditions) \\
Landscape homogeneity \\
Land use and land management \\
Government laws policies
\end{tabular}


The influence of both human and biophysical factors as well as their interactions is immediately apparent in their work. Although they were particularly interested in the causes of mega-fires, they demonstrate how changes in a fire regime can be a function of changes to the biophysical system, the modified natural landscape, or broader social and political factors.

I situate the common proximate causes of fire regime change along a gradient from the biophysical to the human (see Figure 4). Climate and weather are listed on the far end of the biophysical side while fire policy is on the far human end. Land use and burning practices are located in between because they are a function of the interaction of humans and their environment. Below I use the framework to explore the case of fire in the savanna of Mali.

Figure 4. A nature-society continuum of the reasons fire regimes change.

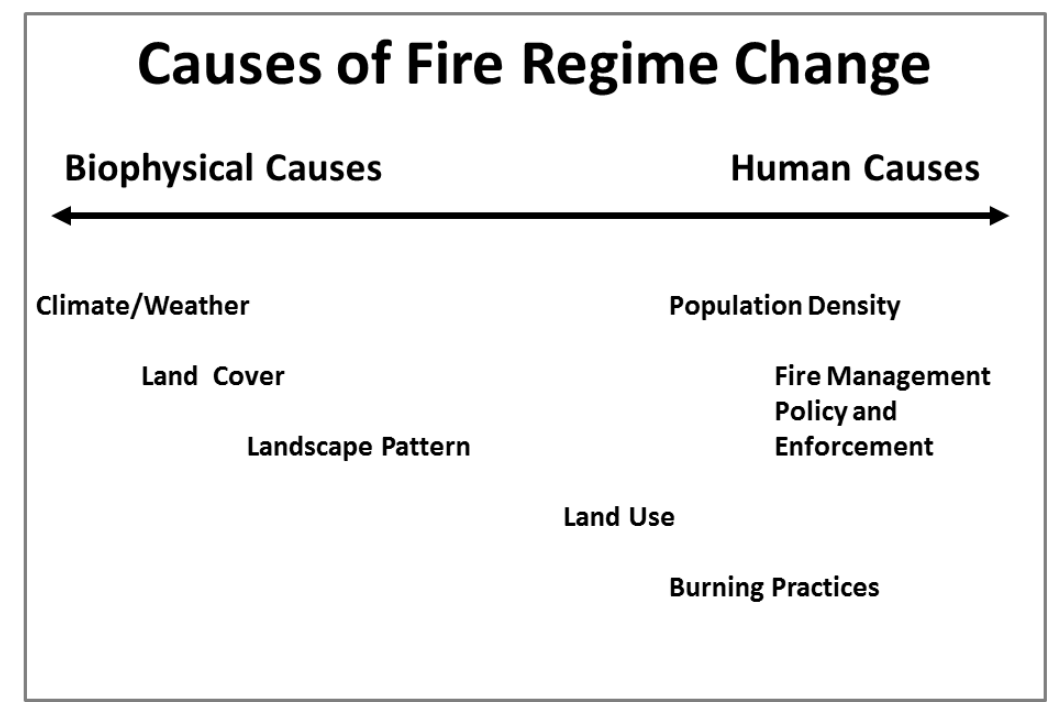

\section{Case Study of Malian Savanna Fire Regimes}

Fire is a frequent phenomenon throughout the Malian Sudanian savanna and although most areas burn annually, fire regimes differ across a landscape. For example, in some areas burning begins very early in the dry season and produces a fine-scale mosaic over time, while in others burning begins later and produces a pattern of later, larger and more contiguous fires (see Figure 5) [23]. Mali has experienced several shifts in fire policy over the past few decades [33,35] as well as a major and prolonged drought making it ideal for a case study.

Fires in Mali, as in most savannas, are predominantly surface fires that burn dry grasses, tree litter and small trees and shrubs. In savanna climates, which are characterized by pronounced wet and dry seasons, fire severity and fuel consumption are in large part a function of fire timing or seasonality [36]. Specifically, fires burning late in the dry season tend to burn more intensely and completely (because vegetation has lower moisture content) and tend to be more damaging to trees (especially juveniles) than fires burning early in the dry season [36,37]. The patterns of savanna fires also tend to vary according to seasonality with smaller, patchy fires occurring early in the dry season and larger, more contiguous fires occurring later. Large fires occur as the landscape becomes more homogeneous in terms of fuel moisture content as the dry season progresses. It should be noted, 
however, that the latter effect is often mediated by the spatiotemporal pattern of fires themselves (see below).

Figure 5. Two distinct fire regimes in the study area for 2002-2003. Note that in area A (Siby) fires begin earlier and create a fine-scale patch-mosaic while in area B (Bougouni) they begin later and are larger and burn more contiguous patches.

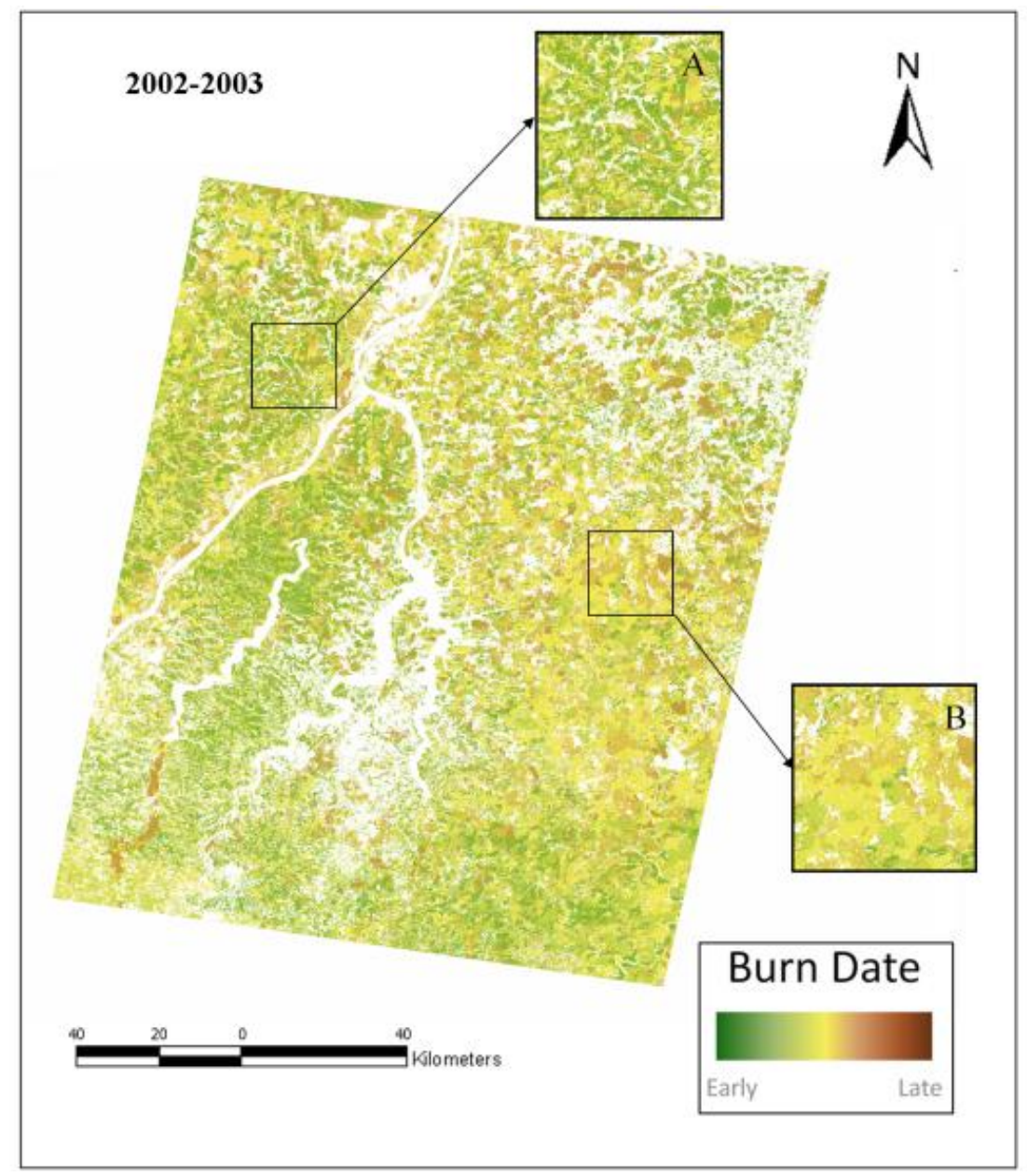

\subsection{Research Approach and Study Area}

This study determines the contemporary reasons for the different fire regimes in two sites located in southern Mali and it examines the historical reasons why these fire regimes have changes over time. Specifically the study explores six potential causes of fire regimes including burning practices, land cover, fire policy, drought, land use and landscape pattern. The methodology combines a long term (over thirty years) burn scar and land cover analysis derived from Landsat imagery with semi-formal interviews of rural inhabitants from multiple villages in the two study areas.

The study areas are located in the Sudanian savanna of southern Mali (see Figure 6). The climate in Southern Mali can generally be divided into three seasons: a hot and dry period from February to June, a warm and rainy season from June to October, and a relatively cooler dry season from October to February. Although the rainy season extends over a five month period, precipitation events are sporadic and often intense and they are concentrated in a period of just 70-80 days [38]. 
Figure 6. Study areas in Southern Mali.

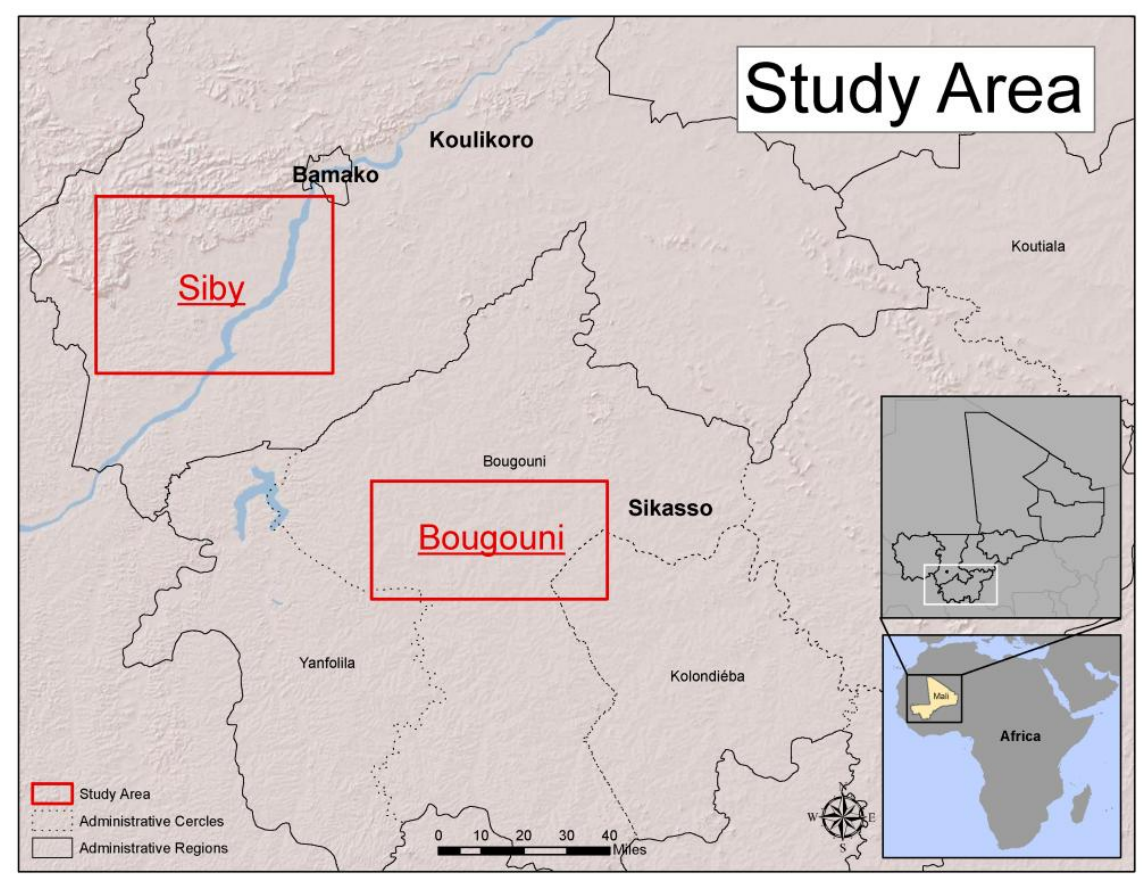

\section{Climate}

Henry [38] determined monthly temperature and precipitation norms for Bamako and Bougouni, key urban areas located in each study region for which there is good climate data. He found the mean annual rainfall is $991.2 \mathrm{~mm}$ for Bamako and 1,176.8 $\mathrm{mm}$ for Bougouni. Notably, a prolonged relatively dry period has affected the entire region for the past 40 years. Average annual rainfall has decreased from 1,065.2 mm/yr to $890.1 \mathrm{~mm} / \mathrm{yr}$ in Bamako since 1970, and from 1,274.4 mm/yr to $1,048.5 \mathrm{~mm} / \mathrm{yr}$ in Bougouni [38].

The fire season follows the rains and runs from November through March, with the bulk of the burning occurring in late December and early January. For this analysis the fire season was divided into three categories based on burn timing (see Table 1): very early (November), early (December), and late dry (January-May). The distinction between very early and early is based on evidence from survey data [28] and analysis of active fires [21] that indicate two peaks in the fires season (see below). The distinction between early and late is based on the 1 January cutoff date for the region set by the Malian Forest Service [39].

\subsection{Land Cover}

Savannas are very heterogeneous environments [40]. The landscape heterogeneity is a function of underlying soil and hydrology, as well as its agricultural use, the combination of which produces unique patterns of land cover [41]. The vegetation in the study area is classified as southern Sudanian savanna and is predominantly composed of a mixture of grasses, trees, and shrubs arranged in a complex mosaic [42]. Ferricrete outcrops on hard pan cover considerable areas. Soil in these areas generally has high gravel content and is very shallow, creating xeric conditions. Unproductive soils such as these support sparse vegetation compared with the deeper, loamy soils in the valleys or 
depressions. Vegetation on hard pan and gravelly soils, referred to here as short grass savanna, is dominated by short, annual grasses (principally Loudetia togoensis but also Andropogon pseudapricus) that are unpalatable for livestock. Short grass savannas are not cultivated and usually have few widely scattered trees. They form up to 25 percent of the savanna in southern Mali, but their distribution is highly uneven [42]. Except for the intensively cultivated areas, a near-continuous layer of tall (over $1 \mathrm{~m}$ in height) perennial grasses principally Andropogon gayanus, Hyparrhenia dissoluta, Cymbopogon giganteus, and Schizachyrium pulchellum) covers the more fertile soils, although there are pockets where the tree canopy is closed and there is little grass cover.

The land cover in settled areas has been significantly modified. Here I use the term land cover to include differences in such factors important to fire regimes such as species type. Species type is critical, for example, because annual grasses tend desiccate more rapidly than perennials during the dry season. Perennial grasses are less common in settled areas (except on long-fallow plots of over fifteen years), and large portions of the occupied landscape are covered by annual grasses, particularly Andropogon pseudapricus and Pennisetum pedicellatum with scattered trees.

The natural heterogeneity (described above) forms the base which is modified through human use. The pattern of natural vegetation is critical, because farmers select only the more fertile lands for agriculture and leave the less productive areas (such as short grass savanna) unfarmed. In addition, the farming system and cycle-whether long term rotational agriculture or a form of more intensive cropping - has important landscape effects. Long fallow cycles can increase landscape heterogeneity by creating a patchwork of fallow plots in different phases of succession which are dominated by different types of grasses as well as tree and shrub cover. A shorter fallow cycle (less than five years for example) tends to produce a more homogeneous pattern composed of predominantly annual grasses mixed with frequently farmed fields.

\subsection{Data}

\subsubsection{Imagery}

The data on burned area for the study areas was generated from burn scar analysis using all available Landsat MSS, TM and ETM+ imagery (Table 2). The data were separated into two clusters, contemporary (2000s) which includes all images from the period December 1999 to May 2007, and historic, which includes all images from 1972 to 1991. Landsat imagery was also used to determine the land cover for two relevant dates.

\subsubsection{Interviews}

All interviews were conducted in the local languages of Bambara and Malinke in 2000 and 2010. Interview and survey questions were based on previous work [28]. Rural inhabitants were asked the following open-ended questions:

i. What are the seasonal patterns of fire you experience in your landscape?

ii. What are the primary uses of fire in your village areas?

iii. What is the relationship between various land cover types and fire timing?

iv. Who is responsible for setting fires and/or regulating fire use in your village? 
v. Have you experienced changes in the fire regime during your lifetime?

vi. If so, what do they believe caused the changes?

Questions were asked of over one hundred individuals and several groups in multiple villages in each study area and involved young as well as very old inhabitants. During the fieldwork phase of the project, the research team also conducted a survey of land-cover for each study site using a GPS and sketch map to record land-cover types along mega-transects extending outwards from the center village. These data were used to ground-truth the satellite image analysis of land cover for the study sites.

Table 2. Landsat images for the study area.

\begin{tabular}{|c|c|c|c|}
\hline Image Date & Average Burn Date & Fire Season & Sensor \\
\hline 16 May 2007 & 30 April 2007 & Late & $\mathrm{TM}$ \\
\hline 25 February 2007 & 17 February 2007 & Late & $\mathrm{TM}$ \\
\hline 9 February 2007 & 1 February 2007 & Late & $\mathrm{TM}$ \\
\hline 24 January 2007 & 16 January 2007 & Late & $\mathrm{TM}$ \\
\hline 8 January 2007 & 31 December 2006 & Early & $\mathrm{TM}$ \\
\hline 21 November 2006 & 13 November 2006 & Early & $\mathrm{TM}$ \\
\hline 5 November 2006 & 20 October 2006 & Very Early & $\mathrm{TM}$ \\
\hline 10 March 2003 & 22 February 2003 & Very Early & $\mathrm{TM}$ \\
\hline 6 February 2003 & 21 January 2003 & Late & ETM+ \\
\hline 5 January 2003 & 28 December 2002 & Late & ETM+ \\
\hline 20 December 2002 & 12 December 2002 & Early & ETM+ \\
\hline 4 December 2002 & 18 November 2002 & Early & ETM+ \\
\hline 24 April 2002 & 31 Mrarch 2002 & Very Early & ETM+ \\
\hline 7 Mrarch 2002 & 5 February 2002 & Late & ETM+ \\
\hline 2 January 2002 & 17 December 2001 & Late & ETM+ \\
\hline 4 Mrarch 2001 & 16 February 2001 & Late & ETM+ \\
\hline 28 November 2000 & 12 November 2000 & Very Early & ETM+ \\
\hline 17 Mrarch 2000 & 1 Mrarch 2000 & Late & ETM+ \\
\hline 13 January 2000 & 28 December 1999 & Early & ETM+ \\
\hline 12 December 1999 & 26 November 1999 & Very Early & ETM+ \\
\hline 4 January 1991 & 18 December 1991 & Early & $\mathrm{TM}$ \\
\hline 22 Mrarch 1990 & 6 Mrarch 1990 & Late & $\mathrm{TM}$ \\
\hline 28 November 1988 & 12 November 1988 & Very Early & $\mathrm{TM}$ \\
\hline 14 November 1986 & 29 October 1986 & Very Early & MSS \\
\hline 16 February 1986 & 31 January 1986 & Late & $\mathrm{TM}$ \\
\hline 14 January 1986 & 28 December 1985 & Early & $\mathrm{TM}$ \\
\hline 7 December 1982 & 28 November 1982 & Very Early & MSS \\
\hline 19 November 1982 & 3 November 1982 & Very Early & MSS \\
\hline 11 November 1975 & 26 October 1975 & Very Early & MSS \\
\hline 23 January 1974 & 7 January 1974 & Late & MSS \\
\hline 5 December 1972 & 19 November 1972 & Very Early & MSS \\
\hline
\end{tabular}




\subsubsection{Analysis}

Burn scar and vegetation mapping were done using ERDAS software. Area calculations as well as statistical and spatial pattern analysis were done using Idrisi (Selva) software (see [23,24] for detailed methods).

\section{Results}

\subsection{Burned Area Maps}

Sample burned area maps are shown in Figure 7. The maps, shown for a variety of dates for comparative purposes, are organized according to early, mid and late fire seasons. Note that the early fire regime in Siby is very regular and burning is far more extensive than that in the Bougouni area. Also, there is usually more burning in Bougouni during the middle of the dry season than for Siby. In addition, the spatiotemporal pattern of burning in Bougouni is very different from that of Siby. In Siby, the burning produces a patch-mosaic of highly fragmented burned areas, while in Bougouni the fires burn larger and more contiguous patches. Figure 8 shows a composite image for the entire fire season of 2002-2003 for both study areas. The contrast in the spatiotemporal patterns of fires is quite evident.

Figure 7. A sample of burn scar maps for different periods for Bougouni and Siby.

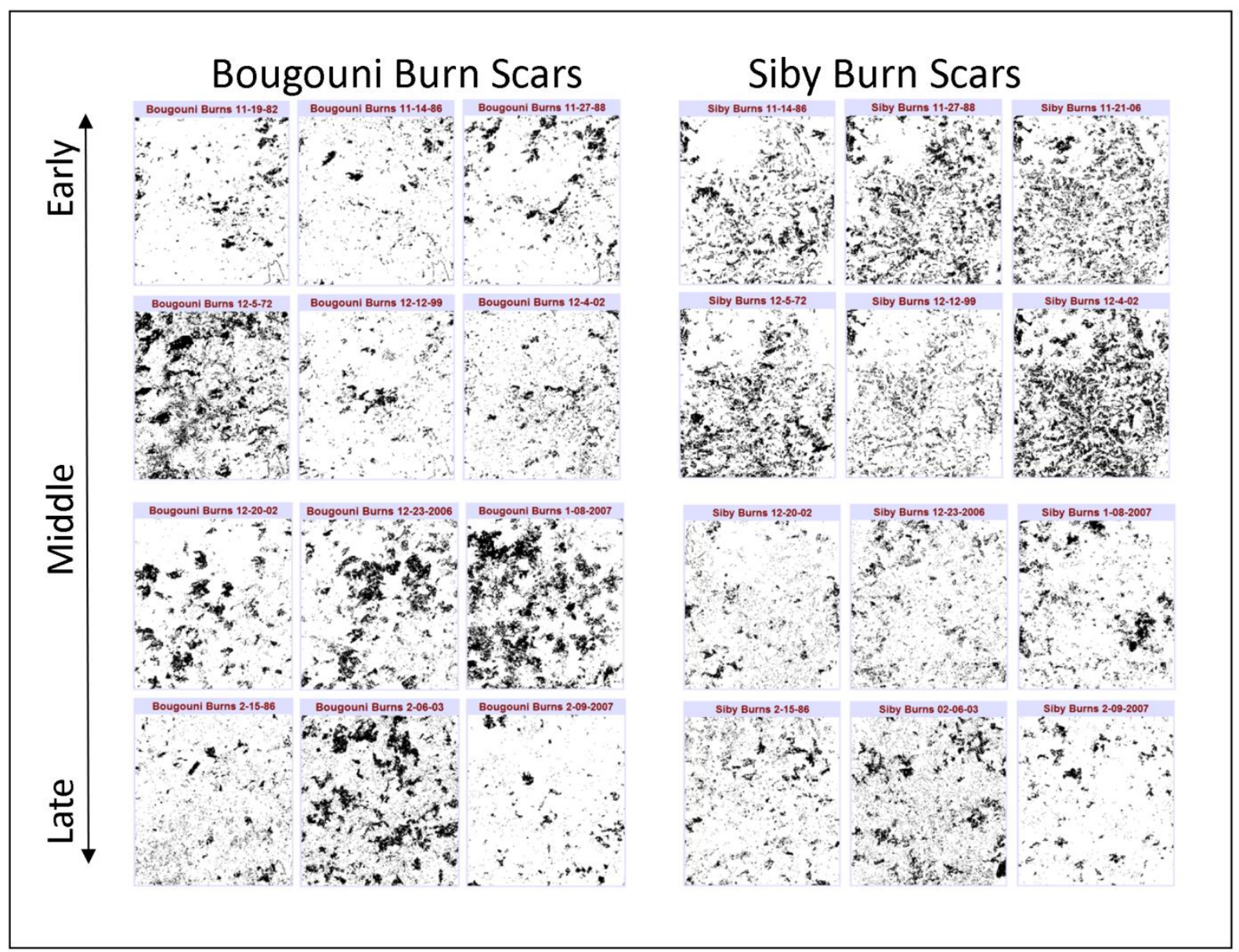


Figure 8. Composite burned area maps for the 2002-2003 fire season for Siby and Bougouni.

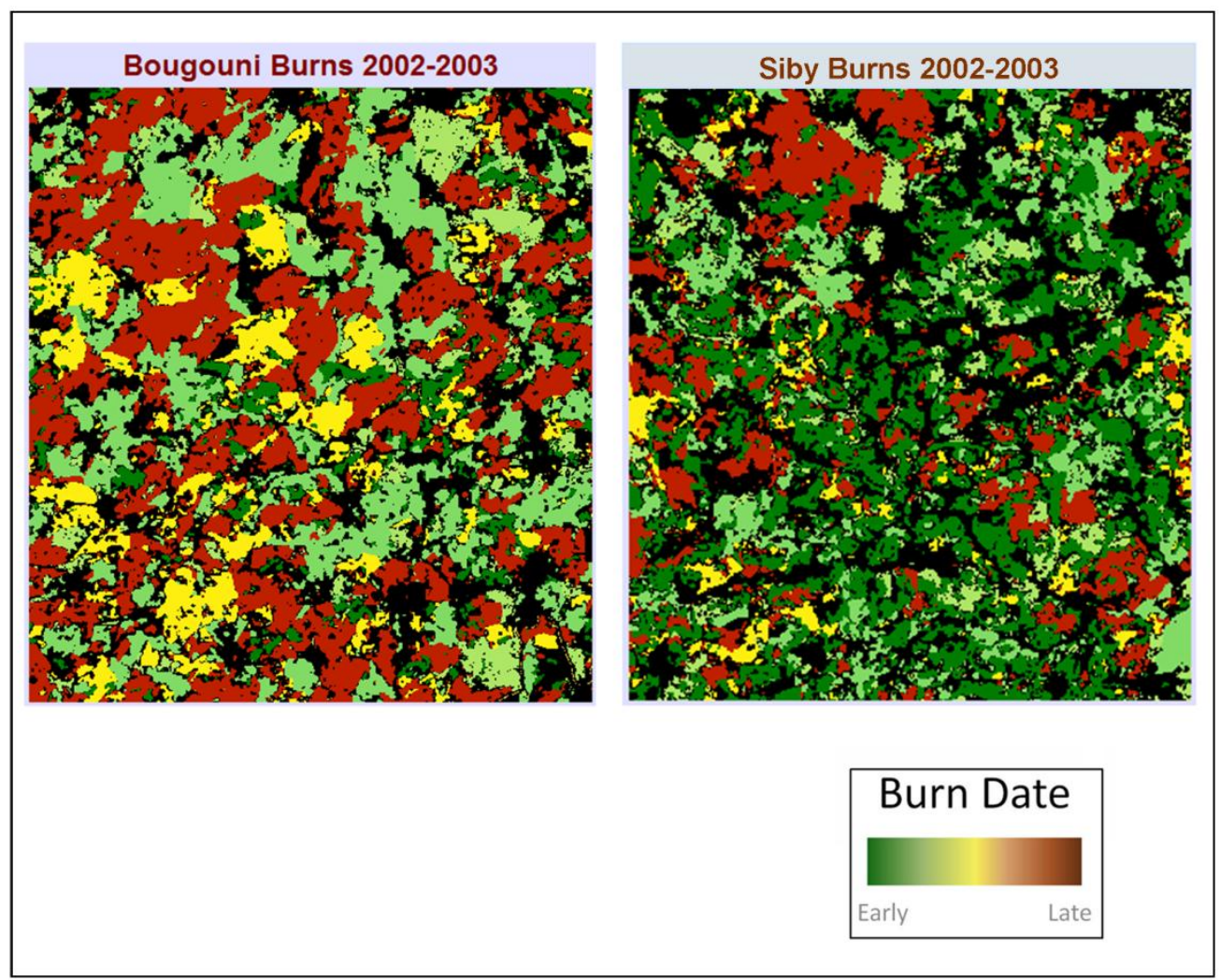

\subsubsection{The Contemporary Period}

Statistical information for the contemporary period (1999-2007) is shown in Figure 9.

Figure 9. Burn frequency as a function of burn date $\left(\mathrm{t}_{1}=1\right.$ November) for Bougouni (a) and Siby (b) for 1999-2007. The graphs indicate that burning begins earlier in Siby and is more evenly spread-out over the fire season.

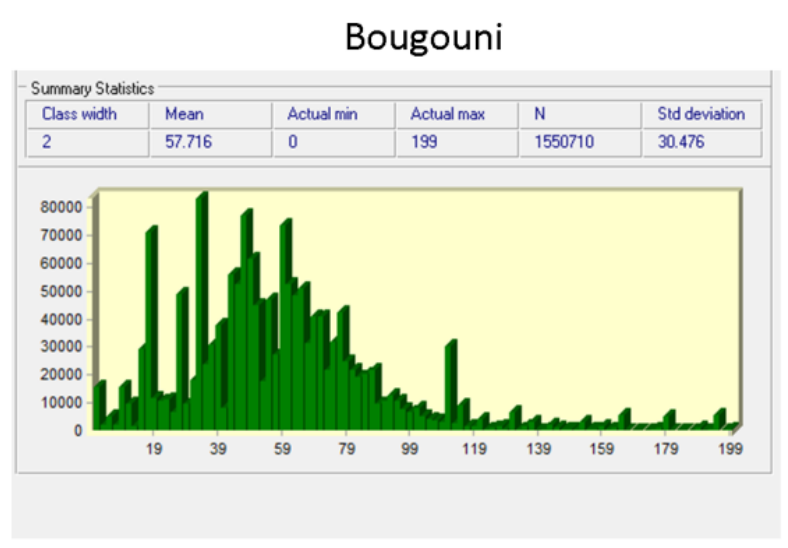

(a)

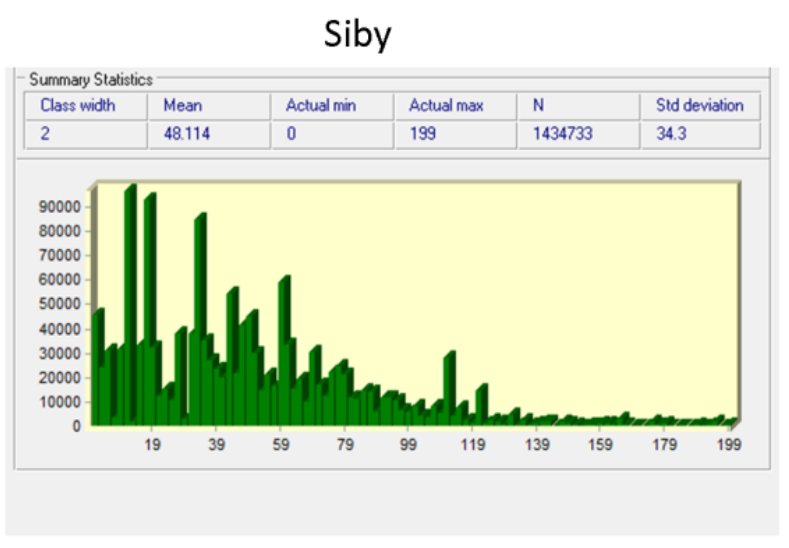

(b)

Comparing the two sites, Siby has a mean burn date of nearly ten days earlier than that of Bougouni (18 December compared to 28 December). This is not entirely surprising given that Bougouni is located further south and, as noted, the rains end later in Bougouni. The histograms illustrate that the 
burning is more evenly spread through-out the fire season in Siby when compared to Bougouni. Perimeter/Area (P/A) analysis performed for the 2002-2003 fire season, finds that Siby has a larger $\mathrm{P} / \mathrm{A}$ ratio (0.315 to 0.272$)$ indicating that burned patches are on average smaller and more fragmented in Siby than in Bougouni, a phenomenon that is quite evident in the burned area maps (Figure 7).

\subsubsection{The Historical Period}

Figure 10 shows the results for the historical period (1972-1991). Here again it is clear that the burn season for Siby is longer and more evenly spread-out than for Bougouni. Surprisingly, however, the mean burn data for fires in Bougouni (42.8 days) is earlier than that for Siby by over 4 days (47.0). For the Siby area the mean burn date for the historic period was approximately the same (one day earlier) than that for the contemporary period. Somewhat surprisingly the mean burn date for the historical period for Bougouni was over two weeks earlier (42.8 compared to 57.7).

Figure 10. Burn frequency as a function of burn date $\left(t_{1}=1\right.$ November) for Bougouni (a) and Siby (b) for the historical period (1972-1991). Here again the fire regime in Bougouni is concentrated over a shorter time period than in Siby.

Bougouni

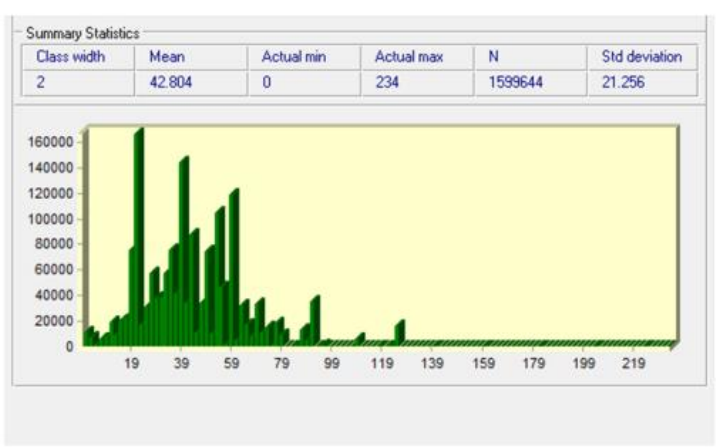

(a)
Siby

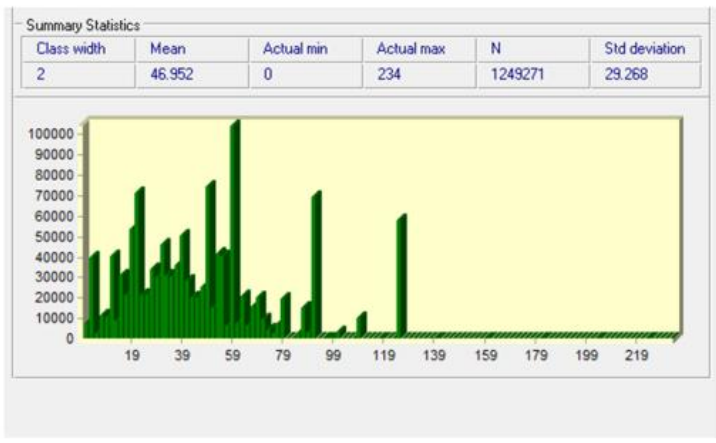

(b)

Figure 11. Contrasting burned area patterns for the Bougouni area for early December 1982 and mid-December 2002.
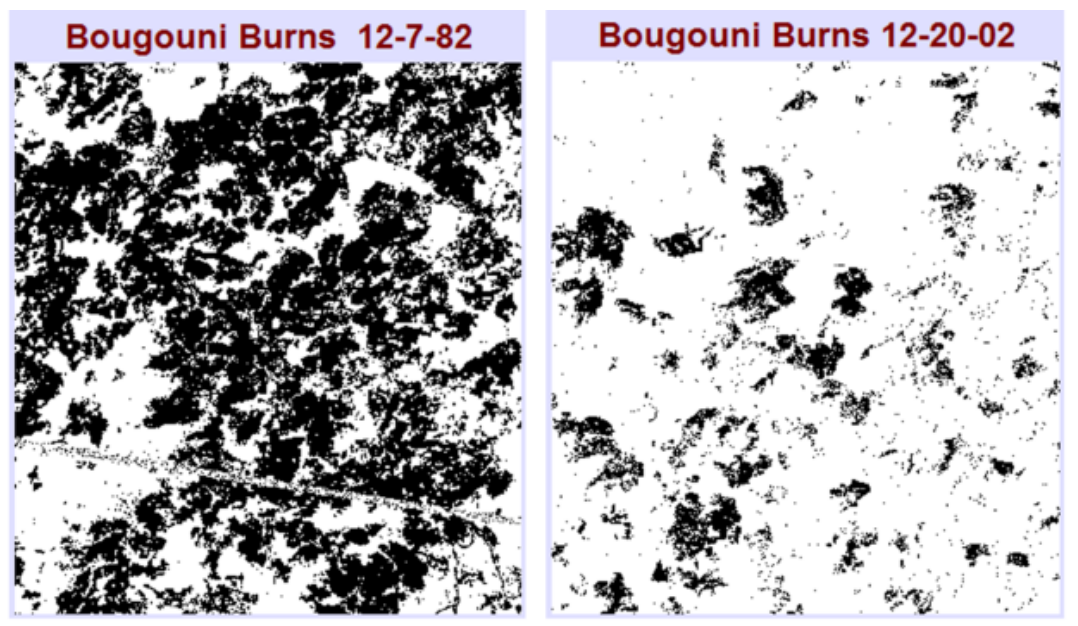
Figure 11 shows a comparison of the burned area patterns for Bougouni for early December 1982 and mid-December 2002. The difference in area burned is striking; indeed, far greater area has been burned by early December in 1982 when compared with all other years from the contemporary period (see Figure 7).

\subsection{Burning Practices}

\subsubsection{Contemporary Period}

Data on burning practices were derived from the semi-structured interviews. Overall, these results find no major differences in the general burning strategies for the two sites. In both areas the overarching goal of burning is to reduce fire hazards and render the landscape useful for a variety of livelihood practices by burning grasses as early as possible (see Table 3 ).

Table 3. Summary of interview and burn scar analysis for the entire study region.

\begin{tabular}{|c|c|c|c|c|}
\hline Land Cover & $\begin{array}{c}\text { Average Burn Date } \\
\text { Based on Image } \\
\text { Analysis } \\
\end{array}$ & $\begin{array}{c}\text { Burn Timing } \\
\text { Based on Survey } \\
\text { Results } \\
\end{array}$ & Rural Calendar & Common Reasons for Burning* \\
\hline \multirow{3}{*}{$\begin{array}{c}\text { Short Fallow/Ag } \\
\text { Long Fallow }\end{array}$} & 8 December & $\begin{array}{l}96 \% \text { of cover type } \\
\text { burned by } \\
31 \text { December }\end{array}$ & Peanut Harvest & \multirow{3}{*}{$\begin{array}{l}\text { To separate areas, clear paths, create } \\
\text { fire breaks, prepare pasture and } \\
\text { hunting grounds, eliminate pests and } \\
\text { danger of late fires }\end{array}$} \\
\hline & 12 December & \multirow{2}{*}{$\begin{array}{l}67 \% \text { of cover type } \\
\text { burned by } \\
31 \text { December }\end{array}$} & \multirow{2}{*}{$\begin{array}{c}\text { Millet and } \\
\text { Cotton Harvest }\end{array}$} & \\
\hline & 22 December & & & \\
\hline $\begin{array}{l}\text { All Other } \\
\text { Savanna }\end{array}$ & 1 January & NA & Harvest End & \multirow{3}{*}{$\begin{array}{l}\text { Hunt, clear grasses and pests to } \\
\text { promote gathering, accidents, } \\
\text { unknown }\end{array}$} \\
\hline Forest/Woodland & 8 January & $\begin{array}{l}36 \% \text { of cover type } \\
\text { burned } 31 \\
\text { December }\end{array}$ & Cool Season & \\
\hline All Cover Types & $\begin{array}{l}24 \text { December } \\
\text { (69\% by } \\
31 \text { December })\end{array}$ & $\begin{array}{l}71 \% \text { of cover type } \\
\text { burned by } \\
31 \text { December }\end{array}$ & & \\
\hline
\end{tabular}

* These are the most common reasons for burning, for details see [29].

According to the interviews, burning in both areas follows the mantra that all grasses have an appropriate time to burn - the point at which they are just dry enough to carry a fire. The burning regime tends to be associated with differences in vegetation cover and especially grass cover. According to the interviews, fires are typically set first to short grass savanna on uplands. These are followed by those set on short fallow lands which are dominated by short annual grasses (Andropogon pseudapricus and Pennisetum pedicellatum) found on deeper, more fertile soils. Taller perennial grasses, such as Andropogon gayanus, are burned later. These grasses tend to dominate on long fallow plots or unfarmed savanna patches on deeper soils. These perennial grasses retain moisture longer and are burned later in the dry season. Grasses in flood plains are burned last, if at all, and often at the start of the rains. The interview data support the results of the image analysis as seen below. 


\subsubsection{Historical Period}

Although the overall burning strategies and practices of the two study areas are quite similar, villagers in the Bougouni area noted two key differences in terms of land cover and land use patterns that are important to consider. The spatial pattern of vegetation types differs between the two sites creating unique opportunities and problems for managing fire. For one, people in Bougouni noted that the early burning of fallow lands has become increasingly problematic over the past decade due to the increase in the area under cotton production (see data below). Cotton fields are intermixed with grain fields and orchards as well as fallow and savanna on the landscape (see Figure 12). As cotton production has increased over time, farmers say they fear setting fallow grasses on fire in advance of the harvest, which is in late December or early January. Farmers pointed out that this has the consequence of pushing the onset of burning to a later date. As several farmers noted, cotton burns "like gasoline". The metaphor is apt in two ways: one, mature cotton will burn very quickly; and two, cotton, like gasoline, is literally money.

Figure 12. The complex farming landscape in Bougouni depicted in an infrared color composite image. Agriculture (white), fallow (fewer and larger trees), orchards (geometric tree patterns) and different savanna types are intermixed in close proximity on the landscape (the red hues, for example, are exposed laterite soil often associated with short grass savanna).

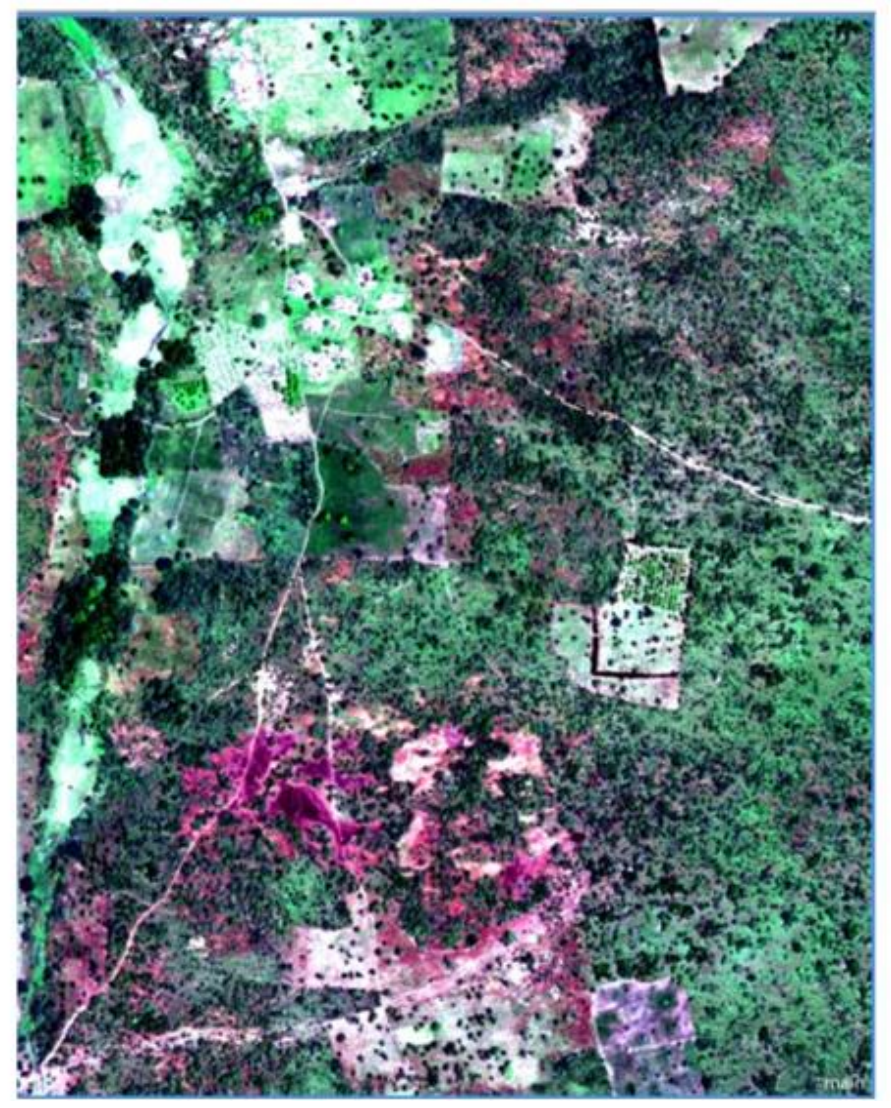

This finding may explain the observed shift to later burning in the Bougouni region over time as farmers grew wary of setting fires before the cotton harvest was in. It is important to note, however, 
that both the Siby and Bougouni sites grow cotton so this factor alone does not explain differences. In addition, both areas have undergone a recent boom in orchards (mango, cashews and bananas) which also require fire protection. People in the Siby area did not indicate that they altered burning out of fear of burning valuable crops, although they did note that fires occasionally cause damage to cash crops.

\subsection{Land Cover and Burning Regimes}

Land cover for both study areas is shown in Figure 13 and Table 4. The most obvious difference between the two sites is that Siby has nearly double the area in short grass savanna compared to Bououni (23.3\% compared to $12.9 \%$ ). In addition, the Siby area is more heterogeneous than Bougouni when all cover types are considered. Fifty-eight percent of the Bougouni landscape is dominated by a single cover class (Savanna and Long Fallow). In Siby, no cover type makes up more than forty percent. Also, the area under agriculture is not significantly different between the two sites.

Figure 13. Land cover for Siby and Bougouni areas. Note the difference in area and pattern of short grass savanna.

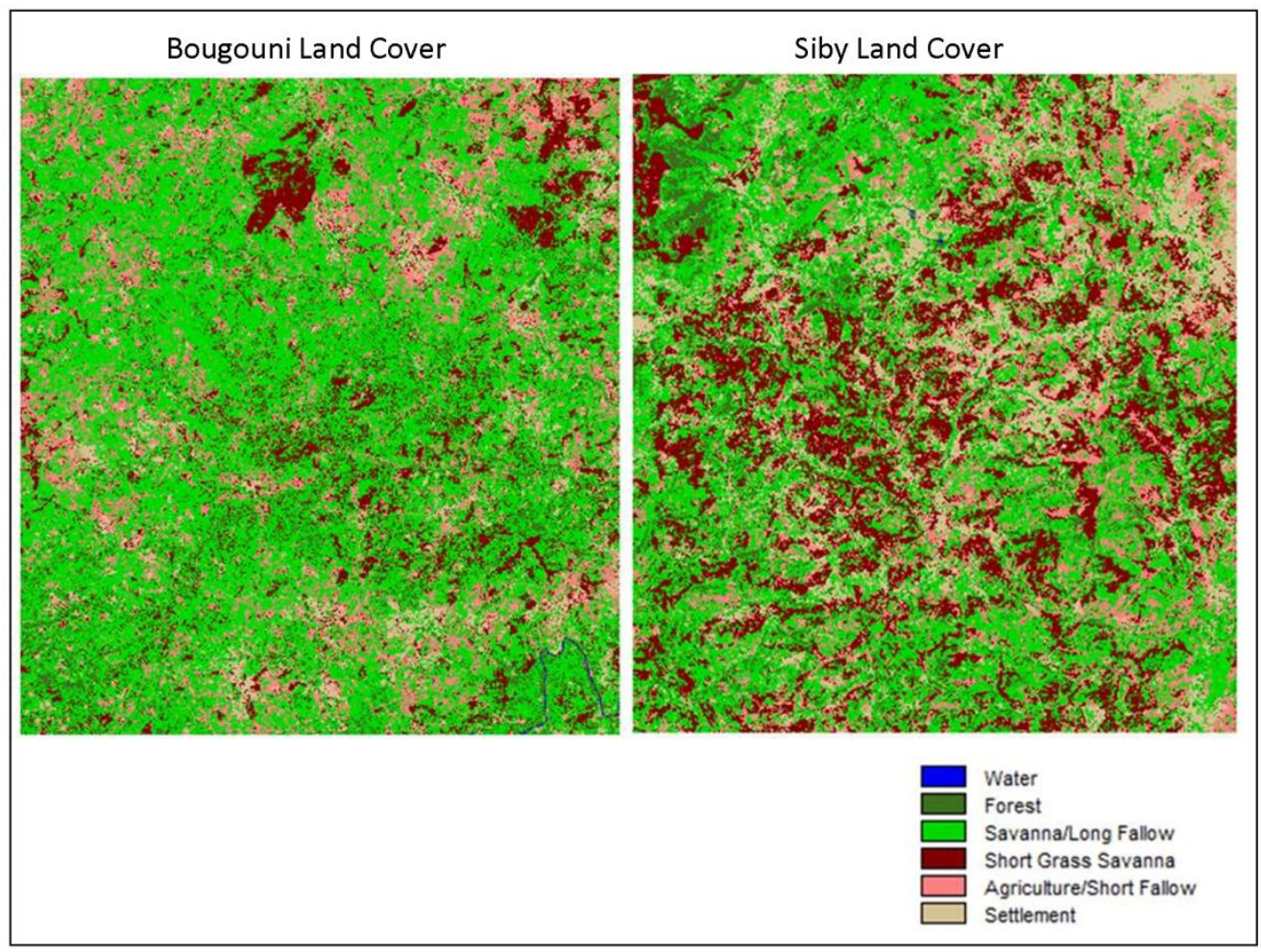

Table 4. Land cover in Bougouni and Siby study areas for 2003.

\begin{tabular}{ccccc}
\hline Cover Type & Bougouni (Ha) & Bougouni $(\%)$ & Siby (Ha) & Siby (\%) \\
\hline Forest & $7,444.2$ & 4.7 & $10,877.5$ & 6.9 \\
Savanna/Long Fallow & $92,137.2$ & 58.4 & $62,464.9$ & 39.6 \\
Short Grass Savanna & $20,322.3$ & 12.9 & $36,675.4$ & 23.3 \\
Agriculture/Short Fallow & $28,091.7$ & 17.8 & $26,129.3$ & 16.6 \\
Settlements/Roads & $9,609.1$ & 6.1 & $21,553.5$ & 13.7 \\
Water & 109.3 & -- & 13.3 & -- \\
TOTAL & 157,714 & 100 & 157,714 & 100 \\
\hline
\end{tabular}


Table 5 shows the average burn dates and standard deviations by vegetation type for both study periods. There is a very clear relationship between burn timing and vegetation type. The data indicate that burning in both study areas follows a similar annual pattern. Fires generally burn short grass savanna first followed by short fallow lands, savanna and long fallow, and finally forest or dense woodland $[23,28]$. As noted, Siby has an earlier mean burn date and more gradual burning regime than Bougouni during the contemporary period. When examined by land cover type, it can be seen this is a result of the differences between the two sites especially the greater amount of short grass savanna in the Siby area. These grasses are burned on average two weeks prior to those in Bougouni. It is also noteworthy that the only cover type that burns later in Siby than in Bougouni is forest. It is probable that this is an outcome of the seasonal mosaic regime that fragments the landscape leaving some patches of forest unburned through a process of fire guarding [23,28]. Some of the areas protected from earlier fires burned at later dates often by fires set for hunting. The data also show that most cover types, regardless of region, burn within approximately one month of their mean burn date (forests being the main exception) which is indicative of seasonal mosaic burning described elsewhere [23].

Table 5. Average Burn Dates and Standard Deviation (in parentheses) by cover type for the contemporary and historic burn periods $(1=1$ November $)$.

\begin{tabular}{ccccc}
\hline & \multicolumn{2}{c}{ Contemporary (1999-2007) } & \multicolumn{2}{c}{ Historic (1972-1991) } \\
\cline { 2 - 5 } & Bougouni & Siby & Bougouni & Siby \\
\hline Short Grass Savanna & $44.5(26.1)$ & $29.2(22.5)$ & $36.0(18.2)$ & $36.6(21.9)$ \\
Agriculture/Short Fallow & $49.2(31.3)$ & $44.3(32.7)$ & $37.6(19.4)$ & $44.3(29.0)$ \\
Savanna/Long Fallow & $61.5(29.4)$ & $59.7(34.5)$ & $44.2(21.4)$ & $52.0(30.7)$ \\
Forest/Woodland & $72.9(35.6)$ & $76.2(36.6)$ & $48.3(24.0)$ & $60.0(33.0)$ \\
All cover types & $57.7(30.5)$ & $48.1(34.3)$ & $42.8(21.3)$ & $47.0(29.3)$ \\
\hline
\end{tabular}

\section{Historical Period}

The historical data indicate a dramatic shift in the burn timing for the Bougouni area. As noted, the average burn date is over two weeks earlier later in the contemporary period. When this shift is examined by vegetation type, it is apparent that every vegetation category burned earlier in the past. Although these differences could be a function of the data sample (which includes the drought years of 1972 and 1982) this does not explain why only Bougouni, and not Siby, experienced a major shift in the timing of the fire regime. Moreover, many drought years are included in the data for both periods of study. Further reasons for these shifts are considered below.

\subsection{Fire Policy}

Anti-fire policy has a long history in the region [35,43]. During the mid-1980s, a universal ban on burning was implemented in Mali that made all savanna fires illegal. Although enforcement of the policy was not effective, in that fire was not suppressed, the penalties assessed to villages did have consequences for the burning regime. According to interview results in both study areas, the anti-fire policy had the short term effect of shifting the onset of burning to a later date. This occurred as villages attempted to halt burning in accordance with policy. People quickly learned, however, that it was not 
possible to prevent fires and that when later fires inevitably broke out they burned more severely and caused damage. Indeed, many people commented that until the anti-fire policy was implemented, they had no idea of the kind of damage fire could cause to property and trees. For example, villagers explained how huts were burned and animals killed by extreme fire events during this period. Although villagers in both areas stressed that the period of suppression was characterized as one with larger and later fires, it is not possible to quantify this with the available sample of historical satellite data. The impact was short term because rural inhabitants quickly realized the need to set fires early to prevent destruction. They resisted the anti-fire policy by setting covert fires [33].

One colorful example illustrates how rural populations reacted to the anti-fire policy to create a "mega-fire". In an effort to forcibly suppress fire, the government enacted a policy of severe fines of populations on land where fires started [33]. Informants told the story that following the implementation of this code there was a rash of large fires including one memorable one that "jumped across the Niger River" and burned through dozens of village landscapes "all the way to the Guinean border". After hearing similar accounts of this story in numerous villages, a key informant explained to me that the story was only partly true. Indeed, there was a great fire, but the cause was not the lack of early burning as one might expect. Instead, the fire spread when villages downwind of the burning set fires to the grasses around their villages in advance of the fire's arrival. They did this in part to prevent damage, but also because they knew that they could claim that the fire came from up-wind and therefore avoid the wrath of the forest service and heavy fines. In this way, the fire did indeed jump the river and burn to Guinea!

After a major change in the Malian government in 1991, the fire code was modified and early burning was formally legalized. Moreover, enforcement of the fire code has been largely discontinued since then [44]. Despite the recent policy shift, people in both study areas claim that there remains a hesitancy to set fires by some. For example, several informants noted that while their fathers set fires, they themselves do not out of fear of causing damage. In part this fear is due to the lingering impacts of the oppressive policy that made setting fires a crime and in part it is due to a lengthy anti-fire campaign that sought to establish a connection between savanna fires and environmental problems such as desertification [33].

Figure 14. Landsat image from January 1986 showing several large fires burning.

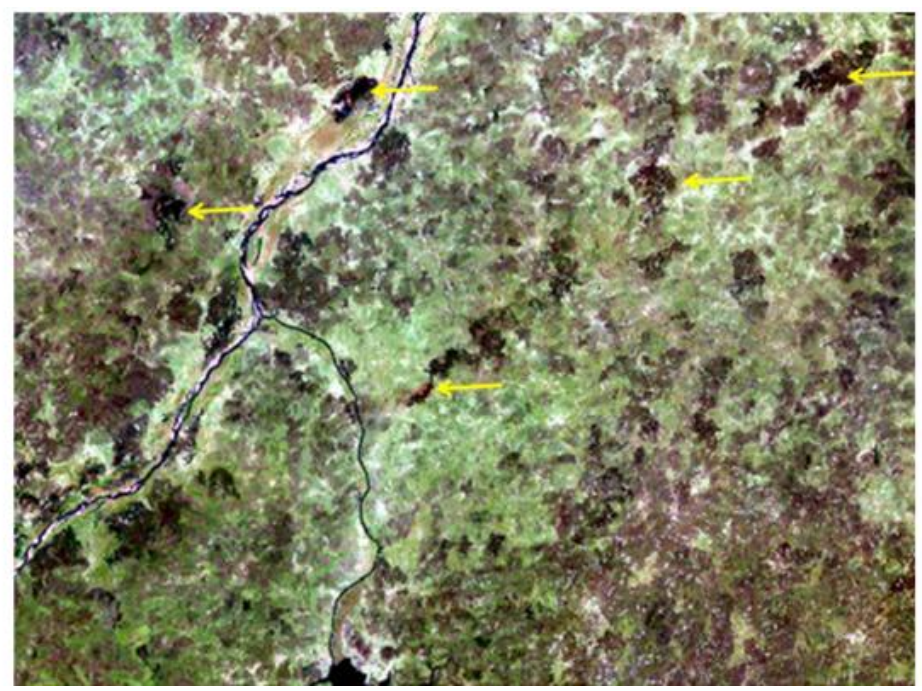


As noted, the burn scar data can neither confirm nor deny claims that fires burned later and more contiguously during the mid-1980s. The images from peak fire season in January 1986 show a number of very large fires burning. Although these images capture active "late" fires burning and large burn scars (see Figure 14) it cannot be demonstrated that these were unusually large or late when compared with other years due to a lack of data. Finally, although the imagery from 1982 (prior to the anti-fire campaign) does indicate that burning was relatively early during this year, it was also a drought year.

In summary, the data indicate that fire suppression policy likely resulted in temporary shift in the fire regime by retarding the onset of early burning. Interviews suggest that one lingering consequence of this policy is that some people remain hesitant to set fires, perhaps contributing to the shift in the later fire onset date in the contemporary period. However, given that the accounts from both study areas were similar, it can be concluded that policy alone does not explain the difference between the regimes at two sites.

\subsection{Drought}

As noted, research using broad-scale data on climate and fire patterns for African savannas has found little correlation between short term patterns of precipitation and the spatiotemporal patterns of fires [20]. The satellite data used in this study are not sufficient for documenting subtle temporal shifts that might result from drought. It should be noted, however, that both contemporary and historic data sets include years of high and low rainfall and that the general burning regime described above tends to hold true in all years for which there is good data.

The interviews suggest that farmers respond to drought by shifting the onset of burning earlier while continuing to follow their general practice of burning. For example, 1982 was a very dry year and the overall burning pattern is consistent for both areas, although it is clear that burning began earlier, especially in Bougouni that year. Interview results suggest that people see early burning as a critical strategy for managing fire in times of drought. One important caveat emerged from the interviews; however, people noted that one impact of long term drought was the change in landscape heterogeneity as it pertains to burning. Numerous farmers noted that drought can influence the fire regime because those landscape patches that previously remained too moist to burn, tend to dry out during prolonged drought, and can carry fire. This drying-out, they noted, impacts landscape heterogeneity making it difficult to conduct the same seasonal-mosaic pattern of burning perhaps resulting in a more homogeneous pattern of fire.

\subsection{Land Use}

\subsubsection{Contemporary Period}

Both study areas have similar land uses combining agroforestry that includes grazing of animals especially during the dry season. Indeed, both study areas are adjacent to large uninhabited sites that attract large herds of animals during the dry months. The crops grown in each area are also similar and include: millet, sorghum, peanuts and cotton. Common trees are mango, cashew and shea nut. 


\subsubsection{Historical Period}

Both study areas have experienced changes in land under agriculture over the past 20 years. In general, two major trends characterize agricultural change: (i) increasing cultivated area over time; and (ii) increasing agricultural intensification (an increase in the percentage of agriculture under annual cropping as opposed to rotational fallow).

Overall the pattern has been one of gradually decreasing expansion of total cultivated area (measured as percent change from beginning to end of each period shown in Table 6) and a simultaneous increase in the percent of annual cropped fields (as estimated by mapping areas in agriculture at both the start and end dates of the period) [45]. An additional and less obvious change associated with the shift to more annually cropped fields has been the increase in cultivated area in cotton. Intensively (annually) cropped fields require fertilizer inputs and loans for fertilizers are only made available to cotton farmers [46]. As such, the shift also reflects an increase in the percentage of land under cotton cultivation.

Table 6. Agriculture change for Bougouni, Siby and the Broader Study Region 1975-2010.

\begin{tabular}{cccc}
\hline Percent Area Annually Cropped & Bougouni & Siby & Entire Landsat Scene \\
\hline $1975-1986$ & 14 & 28 & 23 \\
$1986-1999$ & 21 & 43 & 32 \\
$1999-2010$ & 33 & 43 & 37 \\
\hline Percent Increase in Area in Agriculture & & & \\
\hline $1975-1986$ & 20 & 53 & 29 \\
$1986-1999$ & 23 & -24 & 14 \\
$1999-2010$ & 31 & 0 & 10 \\
\hline
\end{tabular}

\subsection{Landscape Pattern and Heterogeneity}

\subsubsection{Contemporary Period}

As can be seen in the land cover maps, the landscape of the Siby area is more heterogeneous and has a more even distribution of different vegetation types than that of Bougouni. The terrain in Siby is also more undulating with a greater variety of soil types [47]. This tends to create a patchwork pattern of different vegetation forms. In general, the hilltops are less fertile and are dominated by shorter annual grasses with fewer trees than the more fertile and wooded valleys although there is great variation. Part of the Siby area extends onto the Manden plateau where the terrain is highly variable and composed of larger plateaus often dominated with short grass savanna and deep valleys with more dense woody cover and tall grasses. Many of the valley areas are farmed while others remain densely wooded. Uplands composed of short grass savanna are not farmed and are considered "waste-lands" by the local population. As noted elsewhere, the more varied landscape pattern in Siby offers farmers a means to manage fire through mosaic burning allowing them to protect valued crops such as cotton and mango orchards. In short, the mosaic landscape creates opportunities for communities to burn 
grasses with less fear of causing damage to valued food and cash crops. In Bougouni, where there is less natural heterogeneity, people have fewer options for managing fires (see below).

\subsubsection{Historical Period}

As noted above, the land cover data finds that both regions have undergone a shift during the past three decades involving an expansion of the area farmed, the introduction of cotton as a cash crop and a simultaneous intensification of agriculture resulting in more frequently cropped fields and less rotational follow.

\section{Discussion}

The study finds that three interrelated factors are the primary determinants of the fire regime for the study areas in southern Mali: (i) human burning practices; (ii) land cover type; and (iii) landscape pattern. Fire policy, drought and land use play secondary roles; the comparison finds that these three factors differed little between the two study areas and cannot explain the very different fire regimes. In terms of burning practices, the common mantra that every grass has its proper burn time (see quotation above) was repeated often in both study areas - most people agreed that there was an appropriate time to burn grasses and that this was just before the grasses were thoroughly desiccated. Although the desired goal is to burn grasses at the proper time, additional factors play a role in determining the actual burn timing including the landscape pattern and the amount and distribution of cash crops (principally cotton, but also tree orchards).

The differences in the regime of burning in Siby and Bougouni are quite clearly related to differences in the land cover and landscape pattern in the two areas. Siby has a greater degree of landscape heterogeneity and a higher percentage of short grass savanna. In addition, because the short grass cover type is scattered widely and throughout Siby, people are able to burn so as to fragment the landscape in such a way that later fires also burn more fragmented patterns. Conversely, the Bougouni region is burned by larger more contiguous fires that begin later. The Bougouni fire season is also concentrated over a shorter time period presumably due to the fact that there are fewer options to regulate fire due to the lack of landscape heterogeneity.

Although burning practices, land cover and landscape pattern explain most of the differences in fire regimes between the two areas, other factors have influenced shifts in burning regimes when examined over the longer term. The most obvious change in the burning regime was the recent retarding of the onset of burning in the Bougouni zone. As noted, the mean burn date for the contemporary period was two weeks later than for the historical period. Change in agriculture, especially the expansion of cotton area, is the probable cause of the shift in burning. As noted, cotton is highly flammable and as farmers described, they were afraid to set fires until the cotton harvest was complete (usually late December). Indeed, the histograms show that the peak in burning in Bougouni shifted from early to late December over time. While it is not possible to completely rule out drought as a factor in the change, it is unlikely that Bougouni experienced greater drought than Siby which experienced little change in the fires regime over the study period.

Cotton expansion alone does not explain the different shifts observed when comparing Bougouni to Siby over time. After all, cotton farming is quite extensive in the Siby area although the expansion in 
cotton farming appears to have occurred earlier. It can be concluded that the shift in the burning regime observed is a function of the increase in area farmed in cotton within the context of the less heterogeneous Bougouni landscape. In essence, fire management in Siby is easier due to the more varied terrain and the landscape pattern it creates. People in Bougouni have fewer fire management options because grasses dry more uniformly creating a greater risk that if a fire starts, it will burn uncontrollably and cause damage. Indeed, during several field visits to the Bougouni study area, I witnessed frantic efforts by farmers to set back fires to prevent wildfires from spreading onto agricultural lands, such as tree orchards. Farmers were notably frustrated by the lack of fire control and felt helpless. When it was suggested that villages organize to burn fallow lands early to create some protective separation from adjacent areas, people responded by saying that this was a good idea, but that it would require a high level of coordination to avoid causing damage to cotton fields.

The general findings of this study are supported by those of two other recent studies in West Africa. In his study of fire regimes in neighboring Burkina Faso, Devineau [48] also found that the fire regime closely aligns with the vegetation pattern. Similarly, Caillault [49] found that the fire regime follows the vegetation pattern which he determined to be a function of topography and agricultural density. In his model, the overall fire pattern was dictated by topographic influences on vegetation modified by the intensity of farming.

Fire in tropical areas is often argued to be a function of land use, population density or climate change. In tropical forest areas, for example, increasing area in agriculture resulting from population growth often causes in an increase in fire as does drought [50]. In savanna environments, however, the opposite is true - burning is highly prevalent at even very low levels of population density. Indeed, as Caillait's [49] research found, burning is inversely related to population density-as population density increases, the area burned decreases. Others find similar results in other African regions [12,51]. It should be noted that agricultural density (population density) is not particularly high in either the Bougouni or Siby study areas and it is probable that fire regimes change only once a threshold of agricultural density is surpassed.

\section{Conclusions}

This study finds that although many factors interact to determine savanna fire regimes, three interrelated ones largely explain the different fire regimes for the study areas in southern Mali: human burning practices, vegetation cover type and landscape pattern. As such, it is not at all surprising that recent droughts have not resulted in major changes in the Malian fire regime. Indeed, the only event that could possibly be considered a "mega fire" occurred as a result of a failed policy effort to reduce fire. While climate certainly plays a role at a regional level by causing the wet/dry seasons that creates conditions conducive to burning, the variations in the fire regime documented here are primarily dictated by human practices and their interaction with the vegetation patterns on the landscape. It is concluded that land cover determines the fire regime in the savanna of Mali, rather than the fire regime determining the land cover, as is the case in many environments. This is primarily because people utilize the natural variation in landscape pattern to establish a fire regime. Although this finding is for a specific savanna in Mali, evidence from other savannas suggests that the relationship may hold true in other mezic environments as well [49]. As such, if we are going to understand or predict how 
fire regimes will change in the future, it will be necessary to further integrate land change and fire science by developing better linkages between land use, land cover, and fire regimes. For populated mezic savannas in particular, emphasis should be placed on determining how changes in traditional rotational agriculture and other land use practices (as well as future climate shifts), modify grassland species and cover over time as these factors influence when and where people choose to set fires.

\section{Acknowledgements}

The Author would like to thank the National Geographic Society which provided funding for parts of this research. Thanks also to Philip Laris for his editing, Fakuru Camara for his expert assistance in the field, and Michael Shensky for his work on the figures. Finally, thank you to Krystal Burnett for hosting our team in Faradiele.

\section{Conflict of Interest}

The author declares no conflict of interest.

\section{References}

1. Coughlan, M.R.; Petty, A.M. Linking humans and fire: A proposal for a transdisciplinary fire ecology. Int. J. Wildland Fire 2012, 21, 477-487.

2. Intergovernmental Panel on Climate Change (IPCC). Contribution of Working Groups I, II and III; The Fourth Assessment Report of the Intergovernmental Panel on Climate Change; Cambridge University Press: Cambridge, UK. 2007.

3. Pyne, S. Passing the tourch. Am. Sch. J. Manag. 2008, 26, 22-32.

4. Flannigan, M.; Krawchuk, M.A.; de Groot, W.J.; Wotton, B.M.; Gowman, L.M. Implications of changing climate for global wildland fire. Int. J. Wildland Fire 2009, 18, 483-507.

5. Williams, J.; Albright, D.; Hoffmann, A.A.; Eritsov, A.; Moore, P.F.; Mendes de Morais, J.C.; Leonard, M.; Miguel-Ayanz, J.S.; Xanthopoulos, G.; van Lierop, P. Findings and Implications from a Coarse-Scale Global Assessment of Recent Selected Mega-Fires; Food and Agriculture Organization: Rome, Italy, 2011.

6. Schultz, M.G.; Heil, A.; Hoelzemann, J.J.; Spessa, A.; Thonicke, K.; Goldammer, J.G.; Held, A.C.; Pereira, J.M.C.; van het Bolscher, M. Global wildland fire emissions from 1960 to 2000. Glob. Biogeochem. Cy. 2008, 22, GB2002.

7. van der Werf, G.R.; Randerson, J.T.; Giglio, L.; Collatz, G.J.; Kasibhatla, P.S.; Arellano, A.F. Interannual variability in global biomass burning emissions from 1997 to 2004. Atmos. Chem. Phys. 2006, 6, 3423-3441.

8. Dale, V.H.; Joyce, L.A.; McNulty, S.; Neilson, R.P.; Ayres, M.P.; Flannigan, M.D. Climate change and forest disturbances. BioScience 2001, 51, 723-734.

9. Overpeck, J.; Udall, B. Dry times ahead. Science. 2010, 328, 1642-1643.

10. Williams, A.P.; Allen, C.D.; Millar, C.I.; Swetnam, T.W.; Michaelsen, J.; Still, C.J. Forest responses to increasing aridity and warmth in the southwestern United States. Proc. Natl. Acad. Sci. USA 2010, 107, 21289-21294. 
11. Giglio, L.; Randerson, J.T.; van der Werf, G.R.; Kasibhada, P.S.; Collatz, G.j.; Morton, D.C.; de Fries, R.S. Assessing variability and long-term trends in burned area by merging multiple satellite fire products. Biogeosciences 2010, 7, 1171-1186.

12. Grégoire, J.-M.; Eva, H.D.; Belward, A.S.; Palumbo, I.; Simonetti, D.; Brink, A. Effect of land-cover change on Africa's burnt area. Int. J. Wildland Fire 2013, 22, 107-120.

13. National Aeronautics and Space Administration (NASA). Biomass Burning; 2005. Available online: http://earthobservatory.nasa.gov/Features/BiomassBurning/printall.php (accessed on 13 November 2013).

14. Roberts, G.; Wooster, M.J.; Lagoudakis, E. Annual and diurnal African biomass burning temporal dynamics. Biogeosciences 2009, 6, 849-866.

15. Koppmann, R.; Von Czapiewski, K.; Reid, J.S. A review of biomass burning emissions, part I: Gaseous emissions of carbon monoxide, methane, volatile organic compounds, and nitrogen containing compounds. Atmos. Chem. Phys. 2005, 5, 10455-10516.

16. Bond, W.J. What limits trees in $\mathrm{C} 4$ grasslands and savannas? Annu. Rev. Ecol. Evol. Syst. 2008, 39, 641-59.

17. Bond, W.J.; Keeley, J.E. Fire as a global "herbivore": The ecology and evolution of flammable ecosystems. Trend. Ecol. Evol. 2005, 20, 387-394.

18. Krawchuk, M.A.; Moritz, M.A. Constraints on global fire activity vary across a resource gradient. Ecology 2011, 92,121-132.

19. Bird, R.B.; Codding, B.F.; Kauhanen, P.G.; Bird, D.W. Aboriginal hunting buffers climate-driven fire-size variability in Australia's Spinifex grasslands. Proc. Natl. Acad. Sci. USA 2012, 109, 10287-10289.

20. Archibald, S.; Scholes, R.J.; Roy, D.P.; Roberts, G.; Boschetti, L. Southern African fire regimes as revealed by remote sensing. Int. J. Wildland Fire 2010, 19, 861-878.

21. Le Page, Y.; Duarte, O.; Jonsson, P.; Pereira, J. Seasonality of vegetation fires as modified by human action: Observing the deviation from eco-climatic fire regimes. Glob. Ecol. Biogeogr. 2010, 19, 575-588.

22. Nicholson, S.E.; Grist, J.P. A conceptual model for understanding rainfall variability in the west African Sahel on interannual and interdecadal timescales. Int. J. Clim. 2001, 21, 1733-1757.

23. Laris, P. Humanizing savanna biogeography: Linking human practices with ecological patterns in a frequently burned savanna of southern Mali. Ann. Assoc. Am. Geogr. 2011, 101, 1067-1088.

24. Laris, P. Spatiotemporal problems with detecting and mapping mosaic fire regimes with coarse-resolution satellite data in savanna environments. Remote Sens. Environ. 2005, 99, 412-424.

25. Archibald, S.; Staver, A.; Levin S. The evolution of human driven fire regimes in Africa. Proc. Natl. Acad. Sci. USA 2012, 109, 847-852.

26. Moritz, M.A.; Parisien, M.A.; Batllori, E.; Krawchuk, M.A.; Van Dorn, J.; Ganz, D.J.; Hayhoe, K. Climate change and disruption to global fire activity. Ecosphere 2012, 3, 1-22.

27. Russell-Smith, J.; Murphy, B.P.; Meyer, C.P.; Cook, G.D.; Maier, S.; Edwards, A.C.; Schatz, J.; Brocklehurst, P. Improving estimates of savanna burning emissions for greenhouse accounting in northern Australia: Limitations challenges, applications. Int. J. Wildland Fire 2009, 18, 1-18. 
28. Laris, P. Burning the seasonal mosaic preventive burning strategies in the wooded savanna of southern Mali. Human Ecol. 2002, 30, 155-186.

29. Kull, C.A.; Laris, P. Fire Ecology and Fire Politics in Mali and Madagascar. In Tropical Fire Ecology: Climate Change, Land Use and Ecosystem Dynamics; Cochrane, M., Ed.; Springer-Praxis: Chichester, UK, 2009; pp. 171-226.

30. Blaikie, P.; Brookfield, H. Land Degradation and Society; Methuen: London, UK, 1987.

31. Pyne, S. Fire in America: A Cultural History of Wildland and Rural Fire; University of Washington Press: Seattle, WA, USA, 1982.

32. Kull, C. Isle of Fire; University of Chicago Press: Chicago, IL, USA, 2004.

33. Laris, P. Grounding Environmental Narratives: The Impact of a Century of Fighting against Fire in Mali. In African Environment and Development: Rhetoric, Programs, Realities; Moseley, W., Logan, B., Eds.; Ashgate Publishing: London, UK, 2004; pp. 63-85.

34. Lewis, H.T. Fire Technology and Resource Management in Aboriginal North America and Australia. In Resource Managers: North American and Australian Hunter-Gatherers; AAAS Selected Symposium No. 67; Williams, N.M., Hunn, E.S., Eds.; Westview: Boulder, CO, USA, 1982; pp. 45-67.

35. Laris, P.; Wardell, D.A. Good, bad or "necessary evil?": Reinterpreting the colonial burning experiments in the savanna landscapes of West Africa. Geogr. J. 2006, 172, 271-290.

36. Govender, N.; Trollope, W.; Van Wilgen, B. The effect of fire season, fire frequency, rainfall and management on fire intensity in savanna vegetation in South Africa. J. Appl. Ecol. 2006, 43, 748-758.

37. Menaut, J.C.; Lepage, M.; Abbadie, L. Savannas, Woodlands, and Dry Forests in Africa. In Seasonally Dry Tropical Forests; Bullock, S.H., Mooney, H.A., Medina, E., Eds.; Cambridge University Press: Cambridge, UK, 1995; pp. 64-92.

38. Henry, C. An integrated Approach to Estimating Groundwater Storage, Variability and Recharge in Southern Mali, Africa. M.Sc. Thesis, Simon Fraser University, Burnaby, Canada, 2011.

39. Republic du Mali. La Probl'Ematique des Feux de Brousse: Impact and Strat'Egie de Lutte (The Problem of Bush Fires: The Impact and Strategy of the Fight); Minist'ere de l'Environnement et l'Assainissement, Republique du Mali: Bamako, Mali, 2006.

40. de Toit, J.T.; Rogers, K.H.; Biggs, H.C. The Kruger Experience: Ecology and Management of Savanna Heterogeneity; Island Press: Washington, DC, USA, 2003.

41. Duvall, C.S. Biocomplexity from the ground up: Vegetation patterns in a West African savanna landscape. Ann. Assoc. Am. Geogr. 2011, 101, 497-522.

42. Nasi, R.; Sabatier, M. Projet Inventaire des ressources Ligneuses au Mali; Bamako' DNEF: Bamako, Mali, 1988.

43. Fairhead, J.; Leach, M. Reading forest history backwards: the interaction of policy and local land use in Guinea's forest savanna mosaic, 1893-1993. Environ. Hist. 1995, 1, 55-91.

44. Laris, P.; Bakkoury, A. Nouvelles lecons d'une vieille pratique: Mosaique du feu dans la savane du Mali (New lessons from an old practice: Mosaic burning in the savanna of Mali). Bois For. Trop. 2008, 296, 5-16.

45. Laris, P.; Foltz, J.D.; Voorhees, B. Extensification with intensification: The shifting practices of small-holder farmers in the Cotton Belt of Mali. Agric. Syst. 2013, under review. 
46. Laris, P.; Foltz, J.D. Cotton as Catalyst?: The shifting role of fertilizer in Mali's Cotton Belt. Human Ecol. 2013, under review.

47. Projet Inventaire (PIRT). Carte des Formations Vegetales: Bamako-Ouest (Map of Plant Communities: Bamako-West); Ministere de l'Environement et de l'Elevage: Bamako, Mali, 1990.

48. Devineau, J.L.; Fournier, A.; Nignan, S. Savanna fire regimes assessment with MODIS fire data: Their relationship to land cover and plant species distribution in western Burkina Faso (West Africa). J. Arid Environ. 2010, 74, 1092-101.

49. Caillault, S. Le feu, la brousse et la savane: Modelisation spatiale de la dynamique des paysages soudaniens (Burkina Faso). Ph.D. Thesis, University de Caen Basse, Normandie, France, 2011.

50. Cochrane, M.A.; Barber, C.P. Climate change, human land use and future fires in the Amazon. Glob. Chang. Biol. 2009, 15, 601-612.

51. Archibald, S.; Roy, D.; Van Wilgen, B.W.; Scholes, RJ. What limits fire? An examination of the drivers of burnt area in Southern Africa. Glob. Chang. Biol. 2009, 15, 613-630.

(C) 2013 by the authors; licensee MDPI, Basel, Switzerland. This article is an open access article distributed under the terms and conditions of the Creative Commons Attribution license (http://creativecommons.org/licenses/by/3.0/). 